numerary pair of chromosomes may have occurred in $S$. pedo previous to the doubling of the chromosome number.

As regards the structure of the chromosomes, both S. gracilipe and $S$. ephippigera agree in having a $v$-shaped $X$ and a graded serie of acrocentric autosomes. (The arms of the $X$ are nearly equal in $S$. ephippigera, whereas the $X$ of $S$. gracilipes has markedly unequal arms.) The four pairs of $\nabla$-shaped elements present in $S$. pedo in addition to the two pairs of $X$ 's would appear to have evolved by intrachromosomal rearrangements in originally acrocentric chromosomes rather than by centric fusion ${ }^{2}$.

It may be concluded that in the case of Saga pedo, as in the wellknown instances of Artemia, Trichoniscus and Solenobia, polyploidy knor in conju octurs in con unction with partic as distribution and reaches farther north than its diploid bisexual rela tives.

It is of some interest that the largest tetraploid females of the Swiss race of $S$. pedo which formed the material of Matthey's investigation were considerably smaller $(99 \mathrm{~mm}$. total length including ovipositor) than good-sized females of either of the diploid species in positor) that

Details of the cytology of the bisexual species will be published elsewhere.

Thanks are due to Dr. G. Haas, who kindly provided some of the cytological material and who participated in the earlier phases of this study.

Department of Zoology,

E. G.OLDSOHMIDT

The Hebrew University,

Jerusalem.

${ }^{1}$ Matthey, R., Rev. Suisse de Zool., 48 (1941). White, M. J. D., "Animal Cytology and Evolution" (Cambridge, 1945).

\section{Diatoms Without Siliceous Frustules}

DiAToM material freshly gathered during February 1946 from Chichester Harbour was identifled as Navicula ramosissima (Agardh) Cleve. The organism was arranged in flles within a fllamentous muco-gelatinous sheath forming frondose colonies up to $10 \mathrm{~cm}$. in length. When the fllaments were placed in diluted sea-water, differences in osmotic pressure caused the diatom cells to be extruded from the envelope. These cells were taken up with a sterilized pipette and allowed to fall upon the following nutrient agar medium Medium 1): disodium phosphate 0.02 gm., sodium nitrate $0.10 \mathrm{gm}$., soil extract 50 c.c., agar 10 gm., sea-water 1,000 c.c. The colonies were at first very slow to develop, but after several days cell division proceeded fairly regularly for about a week, after which the colonies beeded fairly regularly for about a week, afte

Subcultures were made on another medium (Medium 2) containing disodium phosphate $0.1 \mathrm{gm}$, sodium nitrate $0.2 \mathrm{gm}$., soil extract 50 c.c., disodium phosphate $0 \cdot 1 \mathrm{gm}$., sodium nitrate $0 \cdot 2 \mathrm{gm}$., soll extract 50 c.c., was noted after 48 hours, and reproduction continued for several days. After a week, however, the cultures appeared to be waning, and After a week, however, the cultures appeared the siliceous frustules were being burst open, and the cell contents extruded, enclosed within an intact perizonium, an extremely tenuous membrane which would an intact perizonium, an extremely tenuous mem preparing a mount.

Fres sub-cultures of these naked protoplasmic bodies were made Fresh sub-cul medium. The naked cells retained the characteristic upon the second medium. The naked cells retained the characteristic healthy brown colour of the normal cells, but bore notrace of the markings characteristic or the species. The division of the chromatophores and other cytoplasmic elements appeared to be in every way normal, been the valvar plane. The chromatophores consisted of two flattened bodies oblong-lanceolate in shape, often folded longitudinally, measurbodies oblong-lanceolate in shape, orten folded longitudinally, measuring approximately $22 \mu$ long by $5 \mu$ wide when first liberated. After being cultured for three months, the protoplasmic masses lost a good deal of their rectangularity, became globular and underwent a reduction in size. The cells, devoid of the rigid siliceous frustule, had now lost all normal powers of locomotion and spread themselves slowly over the surface of the agar, forming dense irregularly shaped colonies. After culturing for seven months on Medium 2 all the protoplasmic masses had adopted, more or less, the same globular shape and had a wide between the chromatophores and the perizonium.

Smears of the agar culture were prepared upon glass slides and placed in diatom-free static nutrient sea-water (in 100 c.c. beakers) and in a specially designed dripping apparatus through which the nutrient sea-water (Medium 1) flowed at a rate of about 10 litres in 24 hours. After ten days it was noticed that rich colonies of diatoms had grown over the slide and on the bottom of the beakers and throughout the dripping apparatus. Upon microscopic examination, it was found that the form of the protoplasmic bodies was returning to the naviculoid, although irregularities persisted. Quite a number had regained the power of movement and had formed chains of ten or twelve cells. The new or re-established cells varied from 13.5 to $17 \mu$ in length and from 4 to $5 \mu$ wide. Quantities of culture media kept as controls showed no diatom development.

Very little is known concerning the factors governing the secretion of silica by the diatom cell. Bachrach and Lefevre ${ }^{1,2}$ found that under some unknown cultural conditions certain small marine diatoms failed to produce sfliceous frustules, and such forms showed no signs of decreased virility. A form of Nitzschia closterium, first isolated by Allan and Nelson ${ }^{3}$, has been kept in culture for more than thirty years, and Wilson describes triradiate and oval cells as well as normal ones, but there is no suggestion that the oval cell was produced by the liberation of the protoplasmic mass from the siliceous frustule. Geitler' observed the liberation of protoplasts from frustules of marine diatoms in culture and suggested that the phenomenon was pathological. It is difficult to suggest why the frustules of Navicula ramosissima ejected their protoplasmic masses, as it was not the result of a planned experiment. It seems that it was due to variation in the internal pressure of the cell brought about by the relative concentration of the culture medium. It is unlikely that the failure to produce siliceous frustules while in agar culture was due to exhaustion of the natural silica content of the medium. The re-establishment of the normal naviculoid shape is probably controlled by the flowing of the aqueous medium, for the most active and perfectly re-formed cells were found on the inside of the outlet tube from the dripping apparatus, that is where the rate of flow was greatest.

Acknowledgment is made to Board of Admiralty for permission to publish the foregoing work, which forms part of a general investigation on the antifouling problem relating to ships, in progress in this

N. INGRAM HENDEY

Admiralty Central Metallurgical Labòratory, Emsworth, Hants. Sept. 24.

${ }^{1}$ Bachrach, E., and Lefèvre, M., J. Physiol. et Path.-gen., 27, 241 (1929).

2 Bachrach, E., and Lefèvre, M., Trav. Cryptogram., 281 (1931). s Allan, E. J., and Nelson, E. W., J. Mar. Biol. Assoc., 8, 421 (1910). Wilson, D. P., J. Mar. Biol. As8oc., 26, 235 (1946)

${ }^{5}$ Geitler, L., Archiv. f. Protist., 78, 1 (1932).

\section{Protein of Fruits}

IN continuation of the work on apple-fruit protein, it has been found that if, after the initial treatment of the frozen and ground tissue with alkaline buffers', extraction with this buffer is prolonged for several hours at $1^{\circ} \mathrm{C}$. and the tissue is then washed with a small quantity of the buffer, the combined extract and washings may contain as much as 85 per cent of the original protein. A much larger proportion of non-nitrogenous material is also dispersed into the solution, with the result that when precipitation of the proteincomplex is caused by adjustment of the $p H$ to 6 , the nitrogen content of the precipit ite is only 5 per cent. At $p H$ less than 4 or, if precipitation is brought about by treatment with ammonium sulphate (to halfsaturation), the nitrogen content falls as low as 4 per cent. Of great partially soluble in water or phosphate buffer of $p H$. 8 ; and the resultant solutions, after dialysis at $1^{\circ} \mathrm{C}$., show a positive oxidase action, a strong peroxidase action and a small but definite amylase action (greatly reduced, no doubt, by the presence of tannin). Acid precipitates lannin). Acid are practically insoluble in water and exhibit none of the above enzyme activity.

The nitrogen content of the ammonium sulphate precipitates cannot be raised above 5 per cent by repeated reprecipitations, and the enzyme activity is much reduced during this process, even when care is taken to keep the temperature as low as possible.

A fairly stable complex appears to be involved, and new methods A fairly stable complex appears to be involved, and new methods it undoubtedly contains.

$$
\begin{gathered}
\text { Ditton Laboratory, } \\
\text { East Malling, } \\
\text { Kent. } \\
\text { Sept. } 2 .
\end{gathered}
$$

${ }^{1}$ Hulme, Nature, 158, 58 (1946).

\section{Glycogen Phosphorylysis in Alloxan-diabetic Rats}

IN a previous communication ${ }^{1}$ we reported that the rate of glucose resorption from the small intestine of alkoxan-diabetic animals is increased with the degree of diabetes, and that administration of from the now proved fact that the rate of glucose resorption is dependent on the rate of phosphorylation, we examined whether alloxandiabetic rats show an increase of the rate of phosphorylation. We found that the rate of glycosen phosphorylysis in muscles of alloxandiabetic rats was increased by 63 per cent after 15 minutes and by diabetic rats was increased by 63 per cent after 15 minutes and by 69 per cent after 30 minutes incubation time. By adding insulin in vitro, the rate of glycogen phosphorylation is diminished. We were Montige ${ }^{3}$ that glycogen phosphorylysis in muscle of adrenalectomized ats is lowered.

On measuring the fractions of phosphoric acid in blood by Lohmann's method of hydrolysis, we found an increase of 55 per cent of pyrophosphate, of 58 per cent of hexose phosphoric acid and of 33 per cent
of the amount of total acid soluble phosphorus, as shown in the accompanying table.

FRACTIONS OF PHOSPHORIC ACID IN BLOOD (MGM. PER CENT AVERAGE)

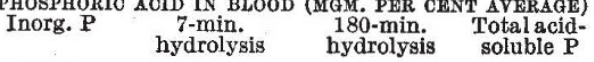

$\begin{array}{lrrrr}\text { Normal } & 3 \cdot 81 & 1 \cdot 81 & 2 \cdot 57 & 25 \cdot 1 \\ \text { Diabetic } & 4 \cdot 29 & 2 \cdot 81 & 4.05 & 33 \cdot 0\end{array}$

Determinations of phosphatase in blood plasma gave the following average results: 26 units in normal animals; 43.4 units in alloxan-
diabetic animals; and 14 units in adrenalectomized ones.

Institute of Physiology L. LASZT

Nutrition Division,

Fribourg.

${ }^{1}$ Laszt, L., Nature, 157, 551 (1946)

2 Schumann, H., Pflitger's Arch., 243, 695 (1940)

${ }^{3}$ Verzár, F., and Montigel, L., Helv. Chim. Acta, 25, 9 (1942).

- Lohmann, K., Biochem. Z., 194, 206 (1928). 